\title{
Children's Understanding and Aspirations on Built Environment: A Case Study on Khulna City of Bangladesh
}

\author{
Çocukların Yapılı Çevre Üzerine Anlayış ve Beklentileri: \\ Bangladeş'in Khulna Şehrinde Bir Çalışma
}

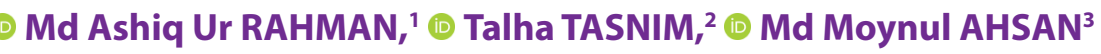

This paper outlines the necessity of planning and design provisions on urban built environment from children's understanding and aspirations' perspective. Their understanding and aspirations are analyzed through survey and a result presentation was prepared using research tools like mind maps, place representation and annotated drawings of dream neighborhood by 271 children of class 5 and class 8 from three renowned schools of Khulna, Bangladesh. Khulna, as a divisional city, is under rapid urbanization process, therefore, facing mounting pressure to build a child-friendly and livable environment which will support its growing urban population and future generations. Thereby, identifying children's understanding of built environment and highlighting their aspirations, this paper also provides solution measures for future planning and design within its scope. Thereafter, with a systematic review of Khulna Development Authority prepared structure plan, referring to the aspired child friendly built environment issues, it has been found that most of the planning provisions are available inside the plan document. However, zoning and development control mechanisms as well as maintenance of existing provisions lack the goodwill of respective authorities. Finally, this study reflects that children's participation in the planning process and the level of their cognitive perception is crucial to achieve a sustainable and child friendly built environment.

Keywords: Built environment; children aspiration; Khulna city; planning provision; school children.

Bu çalışmada, kentsel yapılı çevre üzerine planlama ve tasarım kararlarının çocukların anlayış ve beklenti bakış açılarından ana hatlarıyla ortaya konulmaktadır. Bangladeş'in Khulna şehrinde bulunan tanınmış üç okulun beşinci ve sekizinci sınıflarında okuyan 271 çocuk üzerinde zihin haritaları, yer gösterimi ve açıklamalı çizimler gibi araçlar kullanılarak yapılan anketin sonuçlarına göre çocukların anlayış ve beklentileri analiz edilmiştir. Bangladeş'in büyümekte olan şehirlerinden birisi olan Khulna şehri hızlı bir şehirleşme süreci içindedir. Bu nedenle artan şehir nüfusunu ve gelecek nesilleri destekleyecek, çocuk dostu ve yaşanabilir bir çevre inşa etmek baskısı ile karşı karşıyadır. Çocukların yapılı çevre anlayışını tanımlayan ve beklentilerini vurgulayan bu çalışmada, gelecekteki planlar ve tasarımlar için çözüm önerileri de sunulmaktadır. Khulna Geliştirme (Imar) Kurumu tarafından hazırlanan çocuk dostu inşa edilmiş çevre sorunlarını ele alan sistematik bir incelemede, planlama kararlarının çoğunun plan belgesinde mevcut olduğu ortaya konulmuştur. Ancak, imar ve geliştirme kontrol mekanizmalar ile mevcut planlama hükümlerin sürdürülmesi, ilgili makamların iyi niyetinden yoksundur. Sonuç olarak bu çalışma, çocukların planlama sürecine katılımlarının ve kavramsal algı düzeylerinin sürdürülebilir bir çocuk dostu yapılı çevre elde edilmesi için çok önemli olduğunu yansıtmaktadır..

Anahtar sözcükler: Yapılı çevre; çocukların beklentileri; Khulna şehri; planlama kararları; okul çocuğu.

\footnotetext{
'Urban and Rural Planning Discipline, Khulna University, Khulna, Bangladesh

${ }^{2}$ Urban Development Program, BRAC Mymensingh, Mymensingh, Bangladesh

${ }^{3}$ Department of Real Estate Development and Management, Ankara University, Ankara, Turkey

Article arrival date: June 21, 2020 - Accepted for publication: February 03, 2021

Correspondence: Md Moynul AHSAN. e-mail: moynulurp01@gmail.com

○ 2021 Yıldız Teknik Üniversitesi Mimarlık Fakültesi - @ 2021 YIldız Technical University, Faculty of Architecture
} 


\section{Introduction}

Children are always constructing their vision with the surrounding environments, more specifically from nature and the built environment. The surrounding built environment and its complexities fascinate them, like a home or classroom or enclosed space (Rojas, 2013). Again, they gain their aspiration according to their understandings and thinking. The Oxford English Dictionary defines aspiration as "hope or ambition of achieving something'. This hope or ambition is also correlated with the surrounding physical and natural environment and has impact in their life and livelihoods too. For instance, the quality and design of the physical environment where a child lives has the potential to cause or prevent illness, disability or injury (Cummins and Jackson, 2001). To ensure optimal health and development of city children, a childfriendly built environment is a prerequisite (Frank, 2006). As users, children have valuable experiences by extracting which important contribution can be drawn to the process of designing built environment. But the integration of children in planning practices often has little room from preparation to the implementation process. They are mostly the marginalized portion (Nordstrom, 2010). In this context, ensuring critical participation of children in the process of designing built environment will ensure valuing their insights (Nordstrom, 2010) as well as extracting new and fresh ideas that have been ignored over time.

Bangladesh is one of the fastest growing as well as least developed countries in the world (Ahsan, 2017). The urban population size in Bangladesh is 53 million and around $40 \%$ of them are children. It is projected that in the next 30 years, 112 million people (more than double of the present number) will be living in cities (UNICEF Bangladesh, 2020). Therefore, it is important to prepare planned neighbourhood units for the present and future children who is living or will be living in cities. But it is getting increasingly difficult to avail such sustainability because of poor plan implementation process visible throughout the country. The children-related factors are getting very minor attention in the planning process. However, it's welcoming that International NGOs like Save the Children, BRAC, UNICEF and Bangladesh Institute of Planners are taking some actions like organizing round table discussions, providing policy suggestions to the relevant authorities. But the main challenge remains in plan implementation, more especially child friendly or child responsive plan implementation (Save the Children and BIP, 2016).

Khulna, an urbanized divisional city of Bangladesh, is experiencing urban growth and development throughout its city centre and surrounding areas (Ahmed, Mahmud and Islam, 2014). The child friendly spaces and provisions inside the city are getting less interest. But there is a wider scope of work for researchers with similar interests, especially in Khulna. With increasing population, the demand for child friendly built environment in policy, plan and implementation will become harder to catch up if not managed right now.

Therefore, the present article explores the existing knowledge and aspiration of the children regarding the built environment of Khulna city, Bangladesh. School going children were considered as first choice to do this study with, because school is the suitable place where collective activity or action is easy to undertake, and easy to extract lessons from children about issues of planning and built environment through different cognitive pedagogy (Golbeck and Liben, 1988) and at the same time getting acquainted with their thoughts with convenience. In this context, firstly the knowledge level of children about built environment has been presented. Then their perception about built environment has been analysed and at the end, a content analysis has been performed to identify the reflection of children's preference in the existing plan of Khulna city, Bangladesh. Previously no research work has been done considering their contribution, let alone children's participation in plan making process on built environment for Khulna city, Bangladesh. But for the time being, a comparison between the children's aspirations and planning provisions of existing city plans can be the first step towards achieving wider implementation of values of the children.

\section{Built Environment and Children: A Conceptual Overview}

Urbanisation has created a severe impact on children's health and mind especially in cities. Children of poor or middle income families pass their childhood without basic services or supports. In the case of wealthier communities, children live in a way where there is little room for playing outside and socializing. That world is rigidly organized by adults. But for both types of children threats of traffic, violence and pollution are destined (Riggio, 2002).

In the cities, children are the easiest prey for any kind of health hazard, such as obesity due to lower physical activity or neighbourhood design which hinder such activity, and asthma due to environmental and infectious triggers like allergens from moulds, dust mites, pets, cockroaches, tobacco smoke, volatile organic compound and combustion by-products, irritant air pollutant and soy dust. Besides, pedestrian injuries because of limited efforts on reducing traffic speed and volume, routing traffic away from neighbourhoods and building walkways and sidewalks are common. Faulty construction both for home and schools increases the likelihood of falls, fire 
burns, inadequate ventilation and moisture accumulation (Cummins and Jackson, 2001). Cummins and Jackson suggest that a healthy community is not just one with excellent medical care; it is one with an environment that encourages physical activity, social contact and provides healthy air and landscapes (Cummins and Jackson, 2001).

According to Golbeck and Liben (1988) children like and aspire an organized place more than a haphazardly planned place. Children like a planned neighbourhood, not a concrete jungle (Broberg, Marketta and Nora, 2013). In case of mental condition, urban children are facing various complexity. They spend large amount of time in their neighbourhood just after school and home. When children are exposed to stimulating and positive environments from their early life, then fundamental skills on learning, communicating, problem solving and decision making are developed. A walkable neighbourhood with wellconnected streets as well as safe crossing points, footpaths, destinations and low traffic volume with regulated speed limits ensures more physically active children (Evans et al., 2010). Even bicycle usage and green spaces have profound impact on their growing environment or neighbourhood (de Vries et al, 2010: 2309-2311). But higher density level may affect children's development outcomes negatively. Behavioural problems, social withdrawal and poor academic performance are some of the impacts. Besides, neighbourhood safety concerns often influence family rules and restrictions and thereby affect children's opportunity to play outside and experience early local interaction. High density housing is also less popular because of perceived crime, schools' quality, traffic and noise problem as well as neighbourhood aesthetics (Villanueva et al., 2015).

Children younger than 10 years old lack cognitive and perceptual abilities to negotiate complex traffic situations (Kotsanas et al., 2014). But it improves as children grow up, potential to explore grows with their motilities. For children's healthy cognitive development, confidence and competence in building skills are vital. Playing outdoors ensures more contact with nature and thereby affects children's experiences and emotion regulation (Islam et al., 2014). It also influences children's cognitive functioning like attentional capacity and self-discipline. That's why natural play environments are better than physical manmade play areas. All these evidence underpin that built environment is the mutable point of intervention which affects child development (Şensoy and Sarı, 2019).

The international community is also portraying significant attention to ensure child friendly built environment. Article 31 from the Convention on the Rights of the Child (CRC) emphasizes the state's responsibility for ensuring an enabling environment for specific age and culture. The CRC gives recognition to children's play right and leisure activities too, which implies sufficient leisure time and safe/ friendly space provision inside communities (Ahmed and Sohail, 2008). The Habitat Agenda also reflects that focused attention is given to children and youth participation in city, towns and neighbourhoods when planning secure and sustainable human settlements (Ahmed and Sohail, 2008). Nevertheless, in the recent past many efforts have been introduced throughout the world involving children to develop their physical environments. Two of the far-reaching and impactful initiatives are the UNESCO'S Growing up in Cities (GUIC) project and child friendly city initiative (CFCI) by UNICEF. Therefore, this paper is an attempt to showcase the policymakers, urban practitioners and academics about the aspirations of the children to ensure child friendly built environment in a developing country context like Bangladesh in general and Khulna city in particular.

\section{Method of the Study}

Cognitive and perceptual abilities to negotiate complex situations start to develop when the children is about ten years old. (Kotsanas et al., 2014). In Bangladesh, the age group of class 5 and class 8 normally ranges from 1011 and 13-14 respectively, so these groups were chosen to participate in the study to understand children's and adolescent's knowledge variation. Class 5 and class 8 school going children are normally more than 10 years of age in Bangladesh. Their cognitive and perceptual ability, maturity all are growing quickly in a healthy built environment where they live, enjoy, grow and develop. Furthermore, children of this age group start to gain basic social valuation and personal characteristics (Moulton et al., 2015). In this context, this study has selected the cases from class 5 and class 8 school going children from three high schools of Khulna city, Bangladesh, namely (i) Khulna Zilla School; (ii) Government Coronation Girls High School; and (iii) Lions School based on their reputation, year of establishment and gender dimensions. Khulna Zilla School is the oldest one and it is a boy's only school, whereas Government Coronation Girls High School is a girls only school and Lions School provides co-education. All these schools are located in different parts of the city and attracts students from all over the city. A total of 271 students participated in this study, of whom 46 and 54 were form Government Coronation Girls High School's class five and 8 respectively; 53 and 43 were from Lions School's class five and class eight students; 37 and 38 were form Khulna Zilla School's class five and class eight students. It was interesting to explore the variety of responses from children in both classes as well as between boys and girls because gender helps to differentiate their aspirations.

In this study, a survey team has collected data in two different stages: (i) children's perception on urban built 
environment issues such as e.g. housing, traffic and transport, drainage, solid waste, open space and recreation through item rating; and (ii) aspirations of children through annotated drawing. For collecting children's perception on built environment issues, students of the selected schools of Khulna city were asked to write down five distinct problems of Khulna city and their solutions to these problems. The survey team made it clear to them to write down each item on a priority basis from 1-5, that can be referred as 'Item Rating'. This approach was adopted from the tool named 'Place Representation' (Goldbeck and Liben, 1988) and was done with the help of multimedia presentation.

In the second stage, children were asked to draw their dream neighbourhood. This time they were to draw places where they live in a way that reflects their aspirations. The survey team helped the students to annotate the signs/ shapes/pictures they drew as their aspirations. Lastly, data analyses have been done by thematic analysis. Thematic analysis is one of the most common approaches to qualitative research (Bryman, 2005). Here the researcher undertakes a search for themes in transcripts or field notes. Since themes or categories can be recorded continuously they do not have to be seen as rigid. To identify the theme or codes, a pattern matching tool was used in this research. A pattern match involves a correspondence between a theoretical and conceptual expectation pattern and an observed or measured pattern (Trochim, 1985). For this research, this tool was used to generate codes and themes from the perceptions/answers children gave as response to the data collection stage for understanding their perception on built environment issues. In this study, the collected themes and codes from the perceptions have been analysed through mind maps (a graphic technique that provides a universal key to unlock the potential of the brain) which are produced to show prioritised issues and problems and needed solutions.

In addition to thematic analysis, content analysis was used as a method to analyse text data. Content analysis was used as it focuses on the characteristics of language as communication with attention to the content or contextual meaning of the text (McTavish \& Pirro, 1990; Hsieh and Shannon, 2005). The goal of content analysis is "to provide knowledge and understanding of the phenomenon under study" (Downe-Wamboldt, 1992). Therefore, reviewing different planning documents, content analysis was the preferred method in this study.

\section{Results and Discussion}

\section{Children's Perception on Built Environment}

This section illustrates mind maps showing prioritized issues collected form children on problems of Khulna city and their solutions. Here the issues were grouped under themes. This was done by pattern matching. With the help of the search option of Microsoft Word, same types of issues were identified and also the number of students pointed it as problems were found. This exercise was performed for each school and class. Then all the thematic issues and number of vote for them were stored in a Microsoft Excel document. After that those were arranged in descending order. In this way, five most prioritized issues were sorted out. After having all the six classes' views regarding problems of Khulna, Mind Maps were created using Adobe Illustrator software. In the next section all the mind maps are shown along with analytical discussion.

From this mind map it can be clearly seen that traffic jam and drainage problem were the prime issues children wanted to point out. All three of the schools showed the same results. Pink and Sky Blue colour is used to show their similarity. Except those issues, waste management was also a priority. Purple colour is used to show the dissimilar priority issues among schools. The circles shown here are drawn according to priority, giving a weightage value from .1 to .5 where .1 represents the least priority and .5 portrays the highest priority problem. Next mind map shows priority problems identified by class eight students of each school.

Similar to Figure 1, in Figure 2 the students of class 8 also identified traffic jam and waste management problem as the most dominant issues. Besides these, road accidents and drainage problems were pointed out by both age

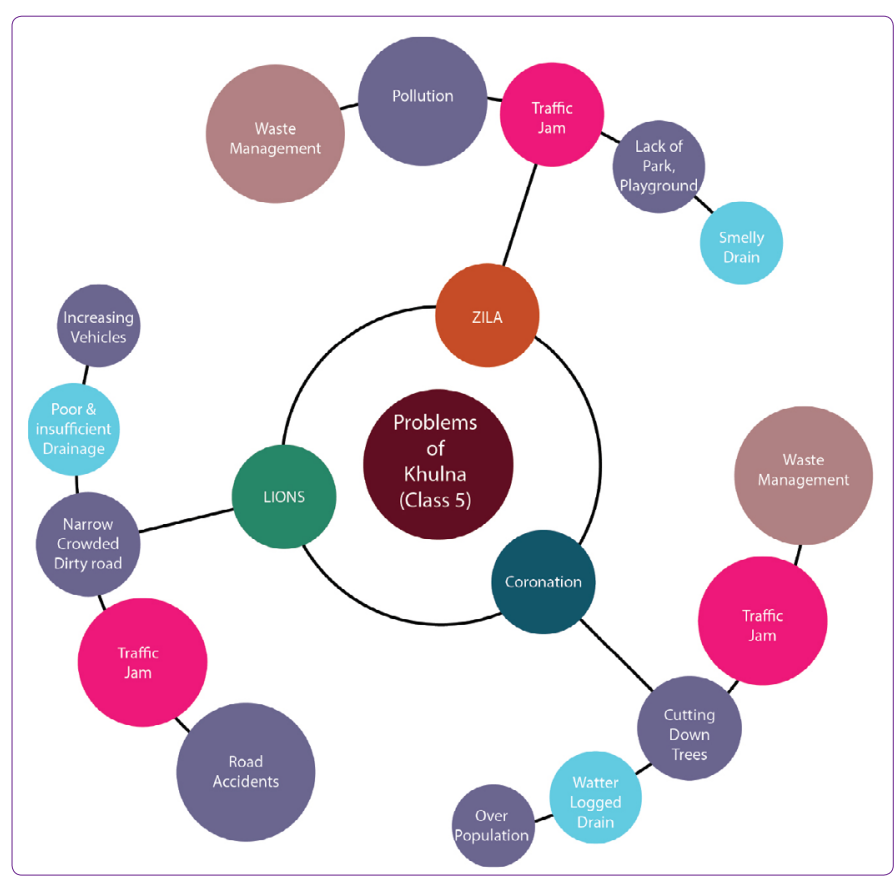

Figure 1. Built environment problems of Khulna city identified by the school going children of Class 5. 
groups of the students. From this evidence it has become clear that for students of both classes, Khulna City's main problems are quite same. The following figure illustrates solutions for the problems given by the class five students of all three schools.

Figure 3 explains various solutions for different problems. The vivid nature of the solution from children

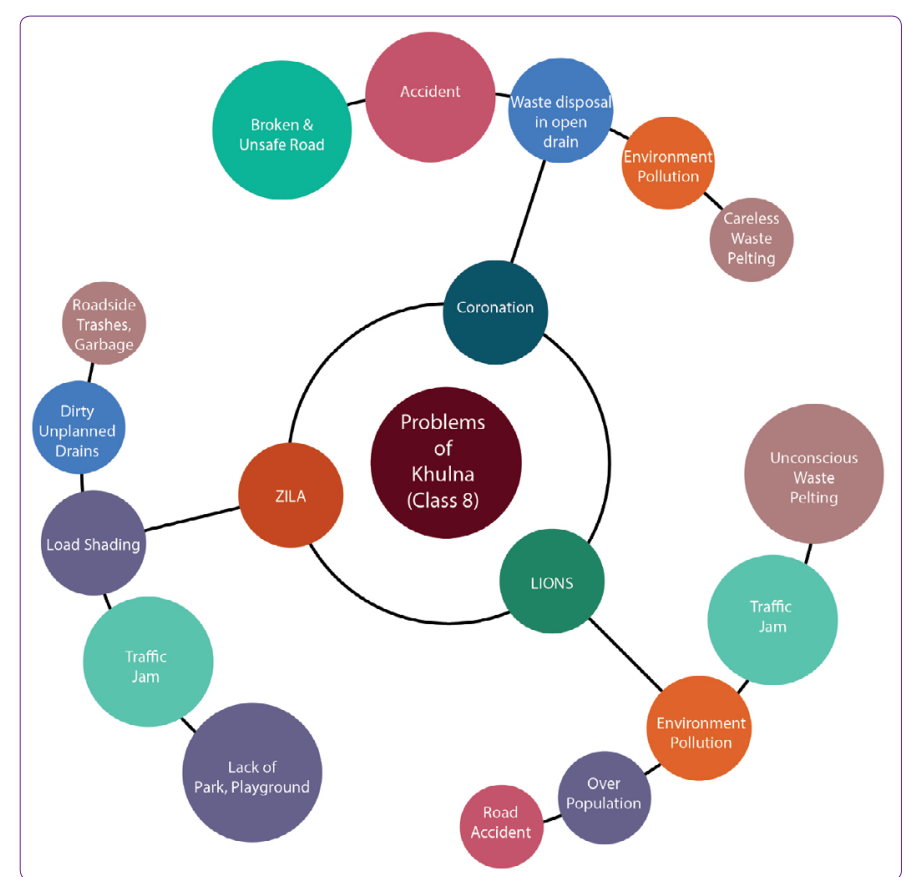

Figure 2. Built environment problems of Khulna city identified by the school going children of Class 8.

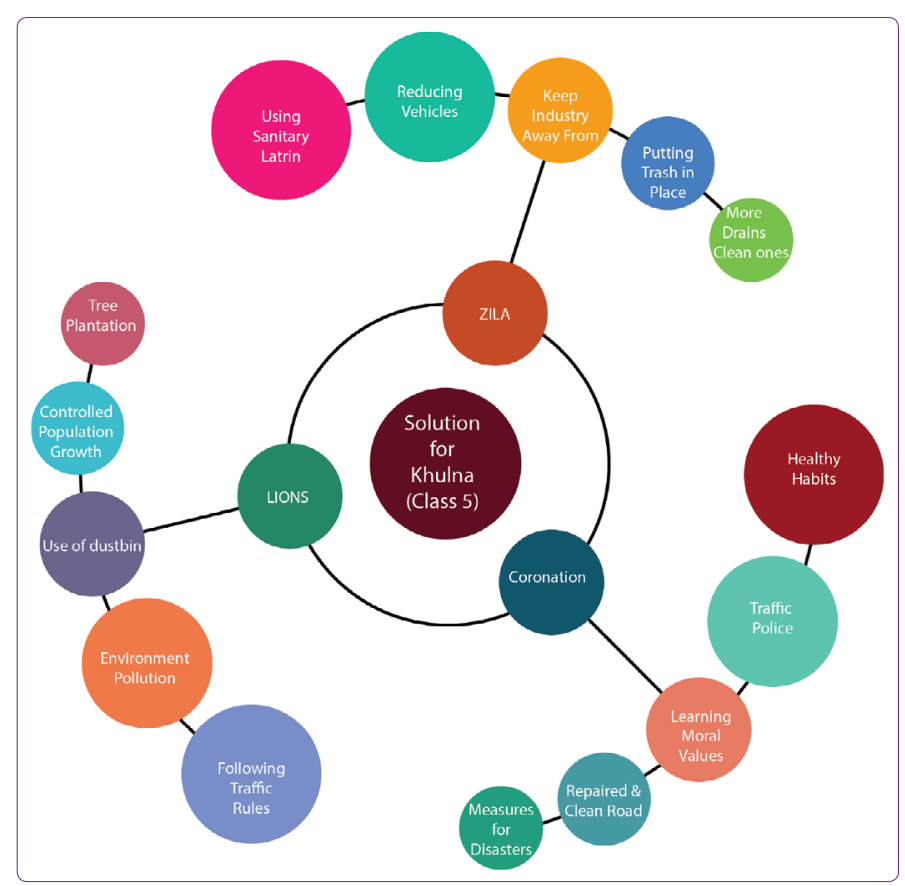

Figure 3. Solutions for built environment problems identified by the school going children of Class 5 . of class 5 from different school makes this map more colourful. This situation reflects children's urge to solve problems through different means. But in the following mental map (Figure 4) students of class eight identified 'Tree Plantation' and 'Dustbin for Garbage' as the most prioritized solutions among other. Besides, public awareness and pre-planned drainage system solutions are similar between two schools. By this student of class eight have proved to be more organized having better cognitive capability between them.

The aforementioned findings on the perception of children on built environment illustrated through different mind maps (Figures 1-4) resembles with the existing literature that has been discussed in the conceptual part of this paper. Most of the students have identified few common built environment problems in Khulna city that includes traffic problems, urban pollution, drainage and waste management, lack of playground, etc. In existing literature, Golbeck and Liben (1988) also explored similar problems and labelled these problems as causal factors for haphazard built environment which they mentioned as the most threatening conditions for cognitive development of children. Evans et al. (2010) also mentioned these problems and asked for better traffic management and green space to ensure child friendly built environment. The perception regarding the possible solutions for built environment problems identified by the school going children in Khulna city, Bangladesh also prioritises better traffic management, more playgrounds and green spaces. Therefore, this paper claims that children have their own perception on urban

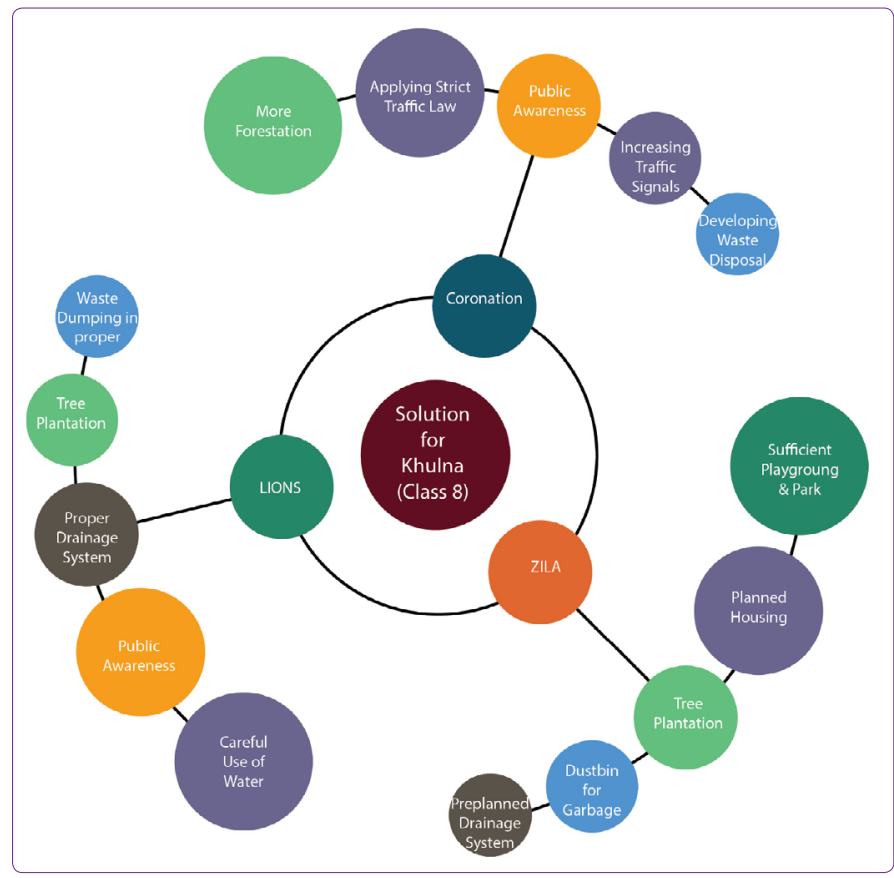

Figure 4. Solutions for built environment problems identified by the school going children of Class 8. 
built environment which is very structured and resembles the present state of knowledge. In this context, this paper assumes that, their aspiration could be really functional for ensuring child friendly urban development. Thus, the following section looks on the children's aspirations on child friendly built environment.

\section{Children's Aspirations on Child Friendly Built Environment}

In this section, children's aspirations which were collected from annotated drawings (Figure 5) have been analysed. Students were provided with an A4 size white paper and they were asked to draw their neighbourhood in a way they like to see it. Each of the students were allowed 45 minutes to draw the picture. All of the 271 students were able to draw the picture and most of the pictures had different built environment items that were illustrated through drawing and sometime students used written explanation. In most of the pictures students labelled different built environment items with the popular name. It was found that the students had a good range of aspirations, ranging from zebra crossings to disabledfriendly transportation, to solid waste management to a better sewage system. As discussed earlier, the surveyed students showed their knowledge and cognitive skills in identifying different urban problems, findings of annotated drawings also justifies that claim.

It has been analysed that among 271 annotated drawings children aspired for 53 different items in their dream neighbourhood (Table 1). The number of aspired items in each drawing ranged between 2 to 17 . The average number of aspired item is 3.89 , but the most frequent number is 4 . Among the aspired items analysed from annotated drawings, the expectation for urban greeneries (explained as trees by the students) topped the list, 132 students aspired for this built environment item. As the students listed out traffic issues in identifying the problems (Figure 1 and 2), they eventually aspired for planned road facilities (aspiration from 128 students). Out of 271 students, 110 students aspired for planned housing while imagining their neighbourhood in the annotated drawing exercise. This finding can be justified with the existing literature as Villanueva et al. (2015) mentioned that quality of housing affects child development. Therefore, it can be concluded that the surveyed students aspired for those built environment items which have been already identified in different literature as the pre-requisites to child-friendly built environments.

In addition to the aforementioned findings, this paper looked at the intensity of aspiration for different built environment items by developing a word cloud by analysing the annotated drawings. From the entire annotated issues identified in Table 1, three different categories were made and given weightage according to the number of times each particular issue was raised. From issues having responses with $132-10$ weightage is 3; from $9-5$ weightage is 2 and from $4-1$ weightage is 1. After giving the weightage values, following word cloud (Figure 6) was generated.

From the figure above, tree, dustbin, playing field, and recreational facility are examples for the higher weightage

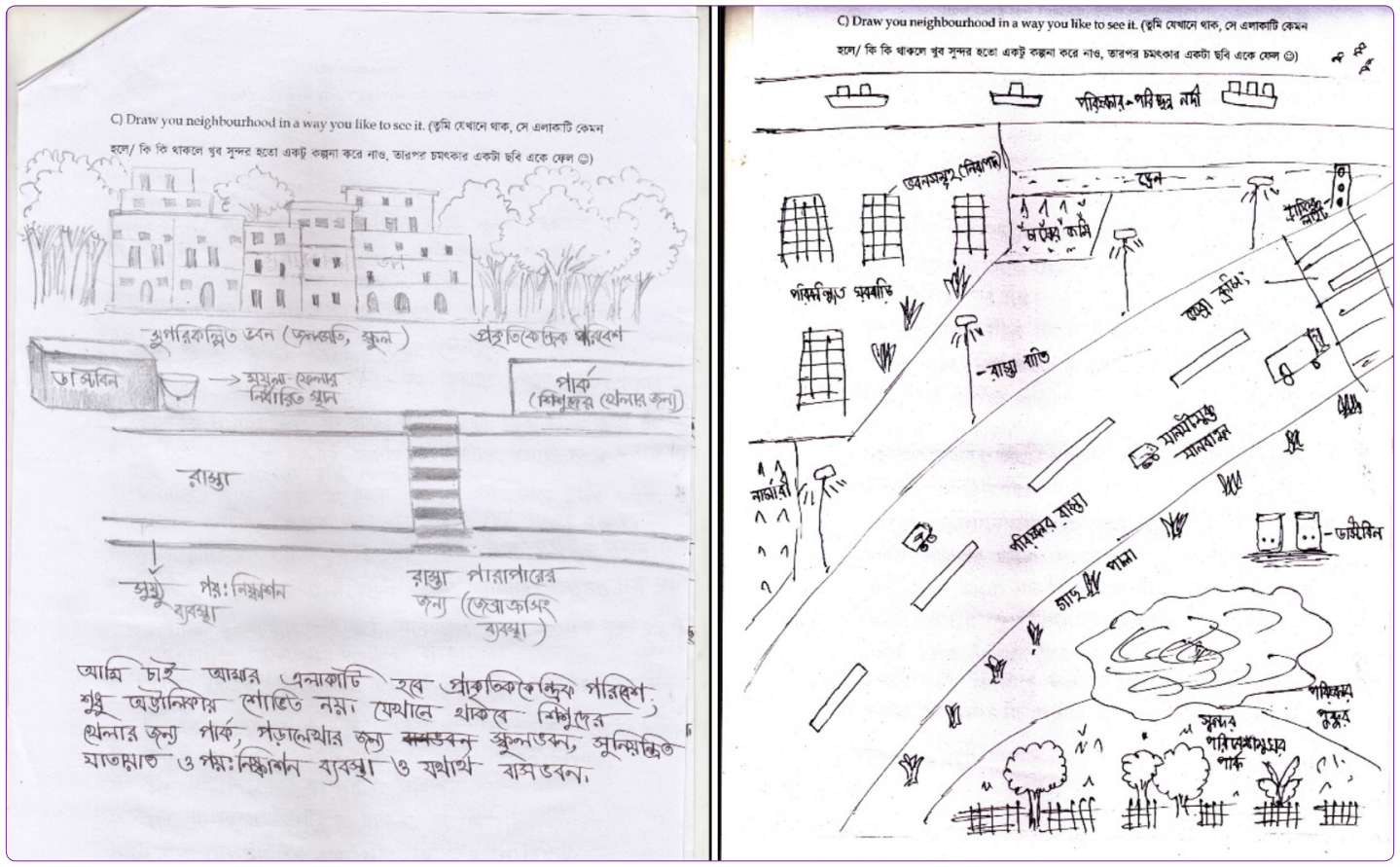

Figure 5. Example of annotated drawing showing children's aspiration for child friendly built environment. 
Table 1. Children's aspirations extracted from annotated drawings

\begin{tabular}{lcccc}
\hline Issues & Responses & Issues & Responses & Issues \\
\hline Tree & 132 & Mosque & 11 & Industry \\
Planned Road & 128 & Pond & 9 & Fire service \\
Planned Housing & 110 & Public Toilet & 8 & College \\
Playing Field & 100 & Tall Building & 8 & Zoo \\
Park & 93 & Vegetation & 7 & University \\
Dustbin & 89 & Lake & 7 & Sports Item \\
School & 48 & Forestation & 7 & Stadium \\
Recreation & 42 & Vehicles & 5 & Speed Breaker \\
Car & 34 & Pollution Free Environment & 5 & Safe Movement for women \\
Garden & 27 & Market & 5 & Rickshaw \\
Traffic Signal & 24 & Crop field & 5 & Playground for Girls \\
River & 19 & Shopping Mall & 4 & Parking lot \\
Planned Urbanization & 17 & Safe Drinking Water & 4 & Parental Support \\
Shop & 14 & Pool & 4 & Library \\
Drainage & 13 & Police Station & 4 & 1 \\
Controlled Population & 12 & Lamp Post & 4 & 1 \\
Zebra Crossing & 11 & Flyover & 4 & 1 \\
Neat and Clean City & 11 & Electricity & 4 & 1 \\
\hline & & & & 1 \\
& & & Girls School
\end{tabular}

words; forestation, lake, river, pond, and drainage are the examples of middle weightage and fire service, zoo, electricity etc. are examples of lower weightage. Therefore, it can be concluded that children has enough cognitive skill to identify the problems of a city and their aspiration is really meaningful to plan a city by ensuring child-friendly built environment. Therefore, it is essential to understand how far the existing planning practice in Khulna city are approaching the aspirations identified by the surveyed 271 students from three different schools in Khulna city of Bangladesh. To do so, the following section reflects on the existing plan of Khulna city that was prepared by Khulna Development Authority in 2001.

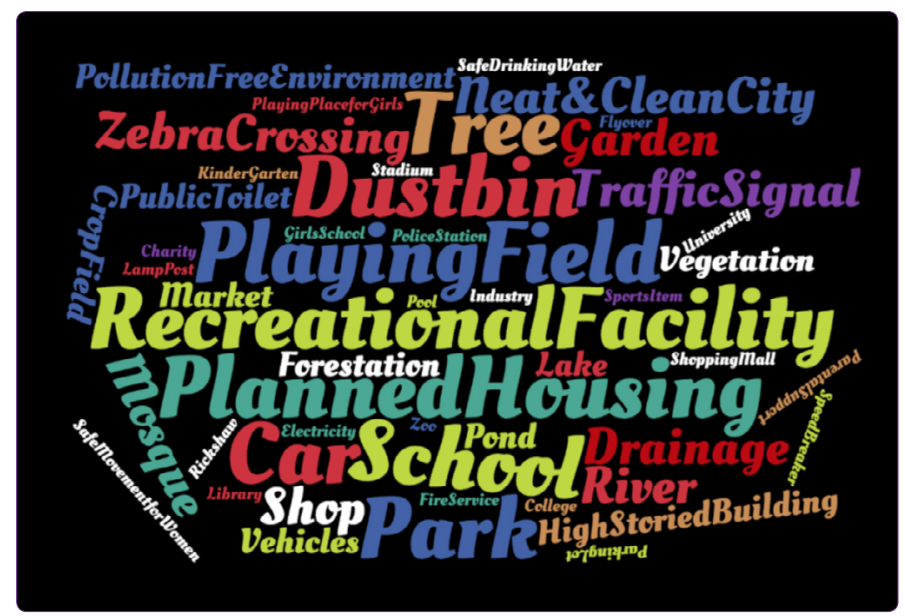

Figure 6. Word cloud showing children's aspiration for child friendly built environment.

\section{Planning Provisions for Child Friendly Built Environment}

From the collected aspirations this paper extracts planning provisions from the structure plan of Khulna through content-analysis. Planning provisions are shown here as the policy recommendation found in the respective chapters. In the chapter six of structure plan of Khulna Development Authority (2001-2020) one of the most aspired issues 'Planned Housing' is aspired along with high storied buildings. Policy recommendations found from this chapter are as follows:

- The development authorities will play the role of facilitators of housing development apart from their existing role;

- Providing assistance to the government agencies in the development of housing schemes;

- Providing assistance to undertake housing schemes under the private sector.

The aforementioned policy documents comply with the aspiration of the children regarding better housing provision to ensure child friendly built environment. The chapter seven of the structure plan of Khulna Development Authority actually covers the aspirations like planned road, regulated traffic, traffic signals, speed breakers, vehicles, lamp post, fly over, safe movement for women, rickshaw and parking lot facilities. The planning provisions that have been narrated in this chapter includes: (i) Incremental road network development; (ii) Introducing efficient city bus service; (iii) Bus terminal/station; (iv)Truck terminal; 
(v) Road network standard; (vi) Neighbourhood level road hierarchy; (vii) Widening of existing roads; (viii) Commuter train service; (ix) Waterway development; and (x) Pedestrian stands and walkways. These provisions, especially policies related to pedestrian walkways are more child friendly. Experts suggested that children who walk to school are more active than those who do not (Kerr et al., 2006). Also children who live near busy roadways tend to have increased exposure to various levels of traffic pollution and negative impacts on their respiratory health (Gill, 2008). They have also suggested to produce route maps showing safer routes to school. These maps often point out sidewalks, crosswalks, crossing guards and residential streets with less traffic as all of these aspects make the route safer.

Chapter twelve of the structure plan of Khulna Development Authority acknowledges the aspirations of children regarding the provision of kindergarten, school, girls' school, collage, university and library. The policy recommendation of this chapter includes the following issues:

- Sufficient number of quality nursery and primary schools should be available at neighbourhood level;

- Sufficient space should be ensured as play field in every school during planning and according official recognition to schools; and

- Education infrastructure for primary, secondary, tertiary levels and vocational training should be emphasized in the master plan.

However, the whole plan fails to address the aspiration for libraries in neighbourhood level. In addition to that the proposed sites of the future schools do not comply with the basic criterion of child friendly built environment. Schools should be placed as such that neighbourhood roads will allow very less traffic through them. Besides, students who come to school by bike or walk are exposed to traffic pollution. So roads should be constructed keeping that in mind. A separate route for biking to school will reduce both money spent on transportation and pollution; and increase physical activity (Gill, 2008).

Regarding the aspirations of the children about the amenities for open space and recreation, chapter thirteen of the structure plan covers these issues. The policy recommendations include: (i) Creation of water front greeneries; (ii) Creation of urban forest; (iii) Creation of highway forest; (iv) Creation of botanical gardens; (v) Development of public Parks; and (vi) Development of playgrounds /stadiums. However, the plan does not acknowledge the provision for neighbourhood park, recreational facility and specified place for girls (Rahman, 2016). While going through literature, it was found that experts have the opinion of : in an inner city neighbourhood, children with 'greener views' from home are better able to concentrate, inhibit initial impulses and delay gratification (Wells, 2000). Again, urban nature provides significant socio-economic, environmental, and psychological benefits to human societies which enriches human life with meanings and emotions. For instance, parks, gardens are also providing economic benefit to the society (Chiesura, 2004). Chapter sixteen of the structure plan of Khulna Development Authority deals with the aspirations of the children regarding environmental management that include pollution free environment, safe drinking water, neat and clean city, river, pond and lake and drainage, dustbin, and public toilets. However, there is no policy guideline to perform any environmental awareness programme in the schools (Horelli, 2007). Moreover, children's aspirations identified in this research were addressed sporadically in the city development plan of Khulna city, Bangladesh but there is no evidence that while preparing the plan, there was a clear intention of the city development authority to prepare a plan that will explicitly cater for child friendly built environment.

\section{Recommendations and Conclusion}

In this study, a method of child centered pedagogy and extraction of children's knowledge about their surrounding built environment was introduced. In the end, an analysis was done to find out present planning provisions according to children's aspirations. In the context of a city in a developing country like Bangladesh, the importance of children's knowledge, attitude and aspirations regarding urban built environment are highly significant, as they can be used to make the built environment safer, more beautiful, healthier, more confortable and convenient, and generally more child friendly. Cities, therefore, need to deploy necessary planning provisions or mechanisms, strategies, and policy actions in their planning and design issues in order to provide a safe, healthy, comfortable, and convenient built environment (Ahsan, 2020). Khulna Development Authority has taken a number of planning provisions and it is also found that most of the planning provisions are there according to children's aspiration but in reality there is a little reflection of those plans when it comes to the implementation stage. Different literature provided an emphasize on education related environmental management and awareness programs in schools. A life skills based approach can determine desired learning outcomes in each school. These lessons should reflect the rights of children in the context of their community, including risk and protective factors in the environment. School children in Khulna city are not getting such opportunities. Therefore, incorporating the aspirations of children will provide healthy planning. The present study claims that students understand different 
planning and built environment issues, they successfully sorted out the major problems of Khulna city with some of their possible solutions as well as they are the future generations, therefore their aspirations to live in a healthy, walkable and pollution free environment is appreciable. Therefore, incorporating children in the planning process will be more fruitful.

\section{References}

Ahmed, A. and Sohail, M., (2008). "Child's Play and Recreation in Dhaka City, Bangladesh", Proceedings of the Institution of Civil Engineers-Municipal Engineer, 2008, Thomas Telford Ltd, pp. 263-270.

Ahmed, I. Mahmud, A. and Islam, S., (2014). "A Study on Historical Transformation of the Urban Integration Core of Khulna City, Bangladesh", International Journal of Innovation and Applied Studies 8(4), pp. 1410-1417

Ahsan M M., (2020). "Strategic decisions on urban built environment to pandemics in Turkey: Lessons from COVID-19". Journal of Urban Management, 9(3), pp.281-285. DOI: https:// doi.org/10.1016/j.jum.2020.07.001.

Ahsan, M.M., (2017). "Role and policy challenges of local governments on environmentally induced displacement and migration in Bangladesh" Mahmut Güler and Menaf Turan (Ed.). The Future Municipalities and the New Approaches Vol.1, pp. 496-507. Istanbul: Marmara Belediyeler Birliği Kültür Yayınları.

Broberg, A., Marketta, K., and Nora F., (2013). "Child-Friendly Urban Structures: Bullerby Revisited", Journal of Environmental Psychology, 35, pp. 110-120.

Bryman, A., (2015). Social research methods, Oxford University Press.

Chiesura, A., (2004). "The role of urban parks for the sustainable city", Landscape and Urban Planning, 68, pp. 129-138.

Cummins, S. K., and Jackson, R. J., (2001). "The Built Environment and Children's Health", Pediatric Clinics of North America, 48, pp. 1241-1252.

de Vries S.I., Hopman-Rock M., Bakker I, Hirasing R.A., van Mechelen W., (2010). "Built environmental correlates of walking and cycling in dutch urban children: results from the SPACE study". Int J Environ Res Public Health. 2010; 7(5), pp. 230924.

Downe-Wamboldt, B., (1992). "Content analysis: method, applications, and issues". Health care for Women International, 13(3), pp. 313-321.

Evans G.W et al., (2010). "Crowding and cognitive development: The mediating role of maternal responsiveness among 36-month-old children", Environment and Behavior, 42, pp. 135-148.

Frank, K.I., (2006). "The potential of youth participation in planning", Journal of Planning Literature, 20, pp. 351-371.

Gill, T., (2008). "Space-oriented children's policy: creating child-friendly communities to improve children's well-being, Children and Society, 22, pp. 136-142.

Golbeck, S.L., and Liben, L.S., (1988). "A cognitive-developmental approach to children's representations of the environment, Children's Environments Quarterly, 5(3), pp. 46-53.
Horelli, L., (2007). “Constructing a theoretical framework for environmental child-friendliness". Children, Youth and Environments, 17(4), pp. 267-292.

Hsieh, H.F. and Shannon, S.E., (2005). "Three approaches to qualitative content analysis". Qualitative health research, 15(9), pp. 1277-1288.

Islam M. Z., Moore R., and Cosco N., (2014). "Child-friendly, active, healthy neighborhoods physical characteristics and children's time outdoors" Environment and Behavior, 48(5), pp. 711-736.

Kerr, J et al., (2006). "Active commuting to school: associations with environment and parental concerns" Medicine and science in sports and exercise, 38(4), pp. 787-794.

Kotsanas, C., Smith, K. and Macnaughton, G., (2014). Creating a Children's Plan with Children, University of Melbourne.

McTavish, D.G. and Pirro, E.B., (1990). "Contextual content analysis". Quality and quantity, 24(3), pp. 245-265.

Moulton V., Flouri E., Joshi H., and Sullivan A., (2015). "The role of aspirations in young children's emotional and behavioural problems", British Educational Research Journal, 41(6), pp. 925-946, https://doi.org/10.1002/berj.3188

Nordstrom, M., (2010). “Children's views on child-friendly environments in different geographical, cultural and social neighbourhoods", Urban Studies, 47(3), pp. 514-528.

Rahman, M.A.U., (2016). "Urban sustainability through strategic planning: A case of metropolitan planning in Khulna city, Bangladesh", Journal of Urban Management, 5(1), pp. 16-22.

Riggio, E., (2002). "Child friendly cities: good governance in the best interests of the child" Environment and Urbanization, 14, pp. 45-58.

Rojas, J., (2013). "Children Are Natural-Born Urban Planners!," Journal of Applied Research on Children: Informing Policy for Children at Risk, 4(2), Article 22. Retrieved from https:// digitalcommons.library.tmc.edu/childrenatrisk/vol4/iss2/22 (Accessed 18 June 2020)

Save the Children and BIP., (2016). "Child-Sensitive Urban Planning", Retrieved from: https://bangladesh.savethechildren. net/sites/bangladesh.savethechildren.net/files/library/ Roundtable\%20Discussion\%200n\%20Child-sensitive\%20 urban\%20planning.pdf (Accessed 20 June 2020).

Şensoy, S A and Sarı, R.M., (2019). "Re-Design of Schoolyard for Effective Development of Child From a Universal Design Perspective", MEGARON, 15(1), pp. 443-445.

Trochim, W. M., (1985). "Pattern matching, validity, and conceptualization in program evaluation". Evaluation Review, 9, 575604.

UNICEF Bangladesh., (2020). "Children in Cities", Retrieved from: https://www.unicef.org/bangladesh/en/children-cities\%C2\%A0 (Accessed 20 June 2020).

Villanueva, K. et al., (2015). "Can the Neighborhood Built Environment Make a Difference in Children's Development? Building the Research Agenda to Create Evidence for PlaceBased Children's Policy", Academic pediatrics, 16(1), pp. 1019.

Wells, N. M., (2000). "At home with nature: effects of "greenness" on children's cognitive functioning" Environment and Behavior, 32, pp. 775-795. 